\title{
Firms and parental justice: should firms contribute to the cost of parenthood and procreation?
}

\author{
Sandrine Blanc ${ }^{1,2,} \dagger$ and Tim Meijers ${ }^{3,4, * \star}$ (D) \\ ${ }^{1}$ INSEEC School of Business and Economics, 27 avenue Claude Vellefaux, 75010 Paris, France; ${ }^{2}$ KU Leuven, \\ Faculty of Economics and Business \& Institute of Philosophy, 3000 Leuven, Belgium. Email: sandrine. \\ blanc@kuleuven.be; ${ }^{3}$ Department of Philosophy and Religious Studies, Utrecht University, Utrecht, the \\ Netherlands and ${ }^{4}$ Institute for Philosophy, Leiden University, the Netherlands \\ *Corresponding author. Email: t.meijers@uu.nl
}

(Received 05 September 2017; revised 05 November 2018; accepted 13 November 2018; first published online 02 April 2019)

\begin{abstract}
This article asks whether firms should contribute to the costs of procreation and parenthood. We explore two sets of arguments. First, we ask what the principle of fair play - central in parental justice debates - implies. We argue that if one defends a pro-sharing view, firms are required to shoulder part of the costs of procreation and parenthood. Second, we turn to the principle of fair equality of opportunity. We argue that compensating firms for costs they incur because their employees decide to procreate or parent may undermine some of the incentives leading to (statistical) discrimination in the workplace.
\end{abstract}

Keywords: parental justice; firms; equality of opportunity; fair play; parental leave; gender equality

\section{The question of firms and parental justice}

Suppose a pregnant woman asks her employers if she can be relieved of heavy work for the duration of her pregnancy, rendering her less productive. ${ }^{1}$ Should the employer be asked to shoulder this cost? When she takes time off to deliver and take care of the newborn, should her employer pay for her leave, for hiring someone to replace her, and for the costs that come with reallocating her duties? And does the father's employer need to contribute to the costs of his parental

\footnotetext{
${ }^{1}$ This question pops up in real life; see, for example, Young vs. UPS. Peggy Young was working as a driver for UPS when she became pregnant in 2006. She requested a few months of light duties - acting on her doctor's advice that she should not lift packages weighing over 20 pounds. In this paper, we address this question by drawing on fairness and statistical and structural discrimination; our approach differs from how this has been discussed in the area of American law, i.e. as an issue of pregnancy discrimination, raising the question of whether Young had been treated less favourably than co-workers similar in their inability to work due to non-pregnancy related disabilities.

${ }^{\dagger}$ Both authors have contributed equally to this paper and are listed in alphabetical order.

(C) The Author(s) 2019. This is an Open Access article, distributed under the terms of the Creative Commons Attribution licence (http://creativecommons.org/licenses/by/4.0/), which permits unrestricted re-use, distribution, and reproduction in any medium, provided the original work is properly cited.
} 
leave and those that come with his absence? Procreation and parenthood impose costs, on the parents, of course, but also on third parties, among them firms. Work probably has to be reorganized - tasks adapted, leave taken, and work duties covered or reallocated, possibly imposing some costs. This raises the question of whether businesses should bear (part of) the work-related costs of pregnancy and parenthood of their employees, that is, play some role in parental justice, which is the question of the fair distribution of the costs of bearing and parenting children. ${ }^{2}$

A related question concerning the role of firms in parental justice was raised recently in France, where about $60 \%$ of the costs of family policies, including child allowance, are funded through 'employers' social contributions', ${ }^{3}$ i.e. by firms. The European landscape is diverse. In 2013 in Sweden, nearly as much as $80 \%$ of the cost of family policy was funded by employers' social contributions. In Germany and the UK, the costs of family policy are covered by individual taxpayers (Beffy et al. 2015: 234). French businesses have lobbied successfully ${ }^{4}$ for a switch to the German model, on the basis that this was necessary for competitiveness and because family allowances were granted universally and not only to those in the labour force. ${ }^{5}$

Despite the practical relevance of the question of the cost of children ${ }^{6}$ for firms, liberal egalitarians have said little about it. There is a growing debate about social justice and firms, ${ }^{7}$ which focuses on the role of firms in the just distribution of social primary goods. Recent contributions have considered how limited liability, workers' participation in corporate governance, or indeed corporate tax may affect the distribution of primary goods such as revenue and resources, power and prerogatives, and the social bases of self-respect. ${ }^{8}$ Much less has been said about the possible role of businesses in specific areas of justice, such as parental justice. ${ }^{9}$

Simultaneously, parental justice is receiving increasing attention from liberal egalitarians, but firms have remained mostly outside the scope of discussions. ${ }^{10}$

\footnotetext{
${ }^{2}$ This refers to Olsaretti's account of parental justice: 'Do nonparents in a just society have an obligation to share with parents some of the costs of having children?' (2013: 227).

${ }^{3}$ This stands for 'contributions sociales patronales'. See, for example, Cahuc and Carcillo (2012). For an overview of the funding of family policy in Europe in 2013, see Beffy et al. (2015).

${ }^{4}$ The measure was part of the so-called 'Pacte de responsabilité' announced in January 2014 and planned to take effect in 2017. See http://www.vie-publique.fr/decouverte-institutions/protection-sociale/politiquefamiliale/comment-branche-famille-securite-sociale-est-elle-financee.html. See also the report by Cour des Comptes, 'Le financement de la branche famille' (2013): https://www.ccomptes.fr/sites/default/files/ EzPublish/rapport_financement_branche_famille.pdf.

${ }^{5}$ See MEDEF (2011: 8).

${ }^{6}$ In this paper, we define the 'cost of children' (or 'costs of children') generally as the costs associated with bearing and raising children, i.e. pregnancy and parenthood. See Section 2 for an expanded definition.

${ }^{7}$ See Hsieh $(2005,2008)$, O'Neill (2008, 2009), Hussain (2009) and Blanc and Al-Amoudi (2013). Firms are not only relevant when it comes to the distribution of money through income, but other justice relevant goods as well. See Herzog and Gheaus (2016).

${ }^{8}$ See, for example, O'Neill $(2008,2009)$, Néron (2015) and, critically, Singer (2015). On the role and shape of corporate tax for justice, see O'Neill (2009). For a Rawlsian view on who should pay for higher education, see Bou-Habib (2010).

${ }^{9} \mathrm{~A}$ notable exception is Hamrouni and Néron's consideration of gender justice in corporations (2017).

${ }^{10} \mathrm{An}$ exception is the debate on parental leave. See Gheaus and Robeyns (2011), Brighouse and Wright (2008) and Alstott (2004: Chs 8 \& 9).
} 
Arguments have turned on whether non-parents should share the costs borne by parents as a matter of fairness. Olsaretti (2013) answers positively for societies in which non-parents benefit from unified welfare systems supported by former generations' children. Tomlin (2015) argues that all young adults are also liable for sharing the costs, as beneficiaries of past parenting acts. An account of the role of firms in parental justice, however, is lacking.

There are two principal reasons why firms matter for parental justice. First, firms share the burdens and benefits of procreation and parenthood. Some of the business-related costs of childbearing and parenting currently fall on firms, and in addition firms may contribute to the non-business costs of parenting, such as funding family allowances (depending on national legislation) or providing childcare facilities and services to parents on a voluntary basis. Simultaneously, firms benefit from the renewal of generations. So, what is the fair share of the benefits and burdens of new generations for firms? Second, an important part of equality of opportunity has to be realized in the workplace. If the distribution of costs among firms and employed parents affects parents' or women's opportunities at work, this must be a concern for liberal egalitarians.

This paper has two aims. First, it asks what philosophical arguments - if any - can back up the intuition that firms have a duty to contribute to the costs of parenthood and in doing so, we provide an account of the role of businesses in questions of parental justice. Second, by doing this, we also aim to refine the pro-sharing account in the fairness debate on parental justice and to offer a refined account of the requirements of equality of opportunity in the workplace. A focus on firms tests the current arguments involved and the proposed institutional implications. Thus, the paper asks whether and on what kind of grounds firms can be required to carry some of the costs of pregnancy and parenthood. Or, instead of contributing, should firms be reimbursed for the costs incurred? This paper considers two distinct grounds for addressing these questions: grounds of fairness in cooperative schemes and grounds of fair equality of opportunity (FEO). Section 2 provides an overview of the economic aspects of pregnancies and parenthood, notably for firms. Sections 3 and 4 consider whether firms should share pregnancy and parenting costs on grounds of fairness. Section 5 examines this same question on grounds of equality of opportunity under non-ideal circumstances.

\section{Firms and the cost of children}

Serena Olsaretti distinguishes between the cost of care and the cost of added adult members (2013: 229). The latter are the general costs involved in meeting whatever claims their children will make as adults ... depending on our conception of justice'. In contrast, the costs of care 'include the loss of freedom, time, and financial resources that caregivers - typically parents - undergo in order to bring up their children and provide for the needs that children have as increasingly less helpless human beings' (Olsaretti 2013: 226). These costs need to be subdivided into optional costs and morally required costs (Olsaretti 2013: 231): some of the things parents want for their children (say, expensive, brandnamed clothes) are optional, whereas others (food, time spent together, 
education) are not. The optional label is a bit misleading. Some morally optional costs are truly optional, like deciding to buy expensive or cheap baby clothes; some of these costs might be beneficial to society, like private lessons. However, some morally optional costs are - as we will discuss in more detail below imposed by society. We might call these socially required costs.

Following Olsaretti, we leave aside the cost of added adults and consider the morally necessary costs of children. We consider, in addition, the morally nonnecessary yet beneficial and the morally non-necessary yet socially required costs of having and raising children. We also take a broader interpretation of 'having children' so as to include both pregnancy and parenthood related costs. Finally, we consider all of the costs of children, beyond those incurred by caregivers. We label these the cost of children.

Within the cost of children, we distinguish between non-business costs (e.g. food, clothing, caregiving time, education) and business-related costs, some of the latter being commonly overlooked. Business-related costs of children include the cost of parents' replacement, of their leave, and of the business being less efficient. Pregnant women and parents need time off work to have and care for their children. For firms, this may generate recruitment costs, such as fees paid to placement agencies, legal costs, training costs if the parent has to be replaced, and the like. Costs of leave include replacement revenue for employed parents on leave or the cost of childcare facilities as an alternative to parental leave. Finally, some costs may result from a possible reduced efficiency of some pregnant women, who might not be able to continue with a heavy-duty job such as lifting heavy packages, for example, or from the cost of finding replacement workers.

Whether firms, the state, or parents actually cover the costs of children depends on states' legal provisions and firms' policies. For example, in welfare states that grant maternity, paternity or parental leave, the costs of children are often shared by all three actors. Other business-related costs are often borne by firms. Olsaretti's enquiry takes a narrow view of the cost of children, focusing mainly on non-business costs and asking whether parents should be supported by taxpayers in bearing these costs. Setting out the issue in these terms overlooks businessrelated costs and an institution that in effect bears some costs in various countries or that one may think should bear some of the costs: the firm. Thus, we also have to ask whether firms should bear some of the costs of children. Three separate questions arise depending on the type of costs we consider, business-related or non-business costs: (1) should firms shoulder business-related costs of children? (2) if not, should they be compensated for these costs and if so by whom? and (3) should firms contribute to the non-business costs of children?

\section{Parental justice as fair cooperation}

Debates on parental justice have focused on the implications of the principle of fairness for the distribution of the non-business costs of children, framing parental justice as a matter of cooperative justice. ${ }^{11}$ In this section, we start the

\footnotetext{
${ }^{11}$ For a similar approach to linguistic justice as cooperative justice, see Van Parijs (2002) and De Briey and Van Parijs (2002). What exactly the role of the principle of fair play is in a theory of distributive justice is an issue that, so far, has been underspecified in the literature and needs further exploration.
} 
argument by setting out the principle of fairness and how it has been used so far in the parental justice debate and ask what the implications are for the question at hand. Fairness is mostly appealed to, implicitly or explicitly, against a background of fair distribution. By considering how people's prospects may be affected by their role within local schemes of cooperation, fairness tells us how to allocate the benefits and burdens of these schemes. When people use their fair share (e.g. of resources) to pursue plans, they incur costs in doing so. Pursuing plans creates benefits - and sometimes costs - for others. How should these costs be distributed? The principle of fair play is a partial answer to this question: when certain conditions are met, they need to be shared among those taking part in the scheme. ${ }^{12}$ For example, the post-tax income of people with similar talents and work motivation, who are therefore entitled to the same prospects on grounds of justice, may vary depending on whether they raise children or not and on how we think fairness plays out in allocating the costs and benefits associated with bearing and raising children. Following the literature on parental justice, we assume a fair background distribution as well as full compliance (i.e. ideal circumstances) unless otherwise stated. We now turn to how the principle has played out in the parental justice debate.

According to the principle of fairness (or fair play ${ }^{13}$ ), we acquire special obligations when a scheme of cooperation involves a 'mutuality of restrictions' (Hart 1955: 185) or whenever we have voluntarily accepted the benefits of the scheme. ${ }^{14}$ According to Rawls, 'we are not to gain from the cooperative efforts of others without doing our fair share' (Rawls 1999: 301. Emphasis added). While the principle of fairness is often discussed in relation to political societies (Hart 1955: 185), it may apply to various other schemes, such as ventures, associations (Rawls 1999: 302) or intergenerational schemes (Gosseries 2004). The implications of fairness depend on the type of scheme under consideration. In political societies, doing one's fair share refers to the duty to comply with the constitution and the law, provided others do the same. ${ }^{15}$ In associations, fairness requires that one carries out the duties of an office one has freely chosen (Rawls 1999: 302). In parental justice, doing one's fair share is usually taken to be, by the pro-sharing view, about non-parents bearing part of the non-business costs of children. Olsaretti, for example, asks whether those who receive benefits have 'an enforceable obligation to do their fair share in maintaining, or bearing the costs of maintaining, the scheme' (2013: 238. Emphasis added).

\footnotetext{
${ }^{12}$ For example, Olsaretti construes parental justice as a question that is distinct from distributive justice: 'we may wonder whether liberal egalitarian justice has something to say about the claims of parents as such, that is, insofar as they are parents, and not insofar as they are disadvantaged fellow citizens or women or both' (Olsaretti 2013: 226-227). See also Tomlin (2015: 664) and, in the domain of linguistic justice, Van Parijs (2002: 60-61) and De Briey and Van Parijs (2002).

${ }^{13} \mathrm{We}$ use 'principle of fairness' and 'fair play' interchangeably.

${ }^{14} \mathrm{Hart}$ and Rawls differ in their assessment of the grounds for obligations: they are mutuality of restrictions for Hart and voluntary acceptance of the benefits of the scheme for Rawls. See Hart (1955: 185) and Rawls (1999: 301).

${ }^{15} \mathrm{Hart}$ evokes the 'obligation to obey the rule' and Rawls 'the natural duty to comply with the constitution'. See Hart (1955: 185) and Rawls (1999: 302).
} 
The implication of fairness for the distribution of the cost of children is, however, highly controversial and two opposing views stand out. According to the 'prosharing' view, fairness requires that non-parents share the cost of children with parents; the 'anti-sharing' view replies that fairness does not require sharing of costs. ${ }^{16}$ As we will see, these different assessments result from contrasting construals of the conditions required for fairness to apply, regarding the benefits associated with additional children, and regarding the characteristics of parents as producers of these benefits.

Some defend pro-sharing with a public goods argument (George 1987). As parents create and raise children, they produce public goods which benefit nonparents, such as a larger tax base, which increases the value of various benefits for all (Olsaretti 2013: 233-234). ${ }^{17}$ Non-parents enjoy these benefits and cannot be excluded from enjoying them. Fairness therefore requires that non-parents share the burdens of producing the source of these benefits, namely children; not contributing would mean free-riding (e.g. Folbre 2008).

Casal and Williams reject this pro-sharing argument, contending that fairness does not apply to the creation and rearing of children. Their view is the result of a detailed discussion of the conditions in which fair play kicks in, which is missing in defences of cost-sharing on public good grounds. They argue that fairness requires sharing costs with producers if and only if the goods created are indeed public goods (non-excludable), the goods result from a cooperative activity, and that those producing the goods incur net costs ${ }^{18}$ (costliness) in order to create the goods (intentionality) (Casal and Williams 1995: 106; Casal 1999: 367). They grant that the social benefits associated with children are public goods but deny that the intentionality and costliness conditions are met. There is no net cost for parents because the benefits of children outweigh the burdens. Besides, parents do not raise children in order to create social benefits. Thus, parents have to bear the costs that come with having children: the fact that they also produce benefits for others is not relevant: non-parents' free-riding is, in this case, morally permissible.

Olsaretti also rejects the public goods argument (for different reasons) but offers alternative grounds for pro-sharing. She too believes that a plausible version of the public goods argument for sharing the costs of children requires intentionality and costliness on parents' side and non-excludability on the side of children. Yet she disputes Casal and Williams' definition of intentionality and costliness and replies that these conditions, well understood, are met. The reason why the public goods argument fails is because some of the central benefits associated with children are not non-excludable. We examine each argument and its implication for the public goods argument in turn.

\footnotetext{
${ }^{16}$ The terms 'pro-sharing' and 'anti-sharing' are borrowed from Olsaretti, who uses 'pro-cost-sharing' and 'anti-cost-sharing' (Olsaretti 2013: 238).

${ }^{17}$ These are, of course, not the only benefits of there being new, well-parented, and well-educated citizens. See Meijers (2016: Ch. 2).

${ }^{18}$ This emphasis on net costs may implicitly rely on an efficiency rationale for cost-sharing: as long as parents enjoy net benefits from having children, there is no need to incentivize them to produce those public goods associated with children. See, for example, De Briey and Van Parijs (2002).
} 
First, Olsaretti agrees that costliness is necessary for fair play to kick in. Otherwise, costless activities that please producers generate obligations for others who just happen to benefit from them. Yet she argues (contra Casal and Williams) that incurred gross costs rather than perceived or net costs for parents is the relevant criterion for costliness. On her view, the principle of fairness requires that all beneficiaries of a cooperative scheme share the gross costs, even if producers are net beneficiaries prior to cost-sharing.

Olsaretti also offers an alternative understanding of intentionality. This condition requires that net contributors intend to contribute. This requirement flows from the context of the application of the principle of fairness, by definition one of intentional participation in a mutually beneficial scheme (Olsaretti 2013: 241). On this view, Casal and Williams' interpretation of intentionality as entailing altruistic motivation is too demanding. When taking steps that benefit others, one intends these consequences even if they are not the reason for acting and the action is not altruistic. Non-altruistic intentionality suffices for fairness to kick in.

Olsaretti argues that costliness and intentionality so understood are present on the parents' side. Parents incur gross costs in having and raising children. Furthermore, costliness is amplified by society's requirements to make children benefit society more. For instance, society requires extensive education, which makes parenting more costly. This reinforces parents' fairness claims regarding cost-sharing. Next, parents do intend to create benefits for society by educating their children. This may be in order to benefit their children rather than for altruistic motives, but parents do this intentionally rather than inadvertently. The public goods argument would seem to grant parents a legitimate claim to cost-sharing.

The public goods argument fails, on Olsaretti's view, not on the production side but on that of the goods produced: the benefits associated with children are excludable. It is possible to exclude non-parents from some of the central benefits of parenting by creating a dual welfare system, for instance a dual public pension system in which only parents benefit from the next generation. ${ }^{19}$ Not all three conditions for fair play are met, so the public goods argument does not apply.

The rejection of the public goods argument, however, is not fatal to cost-sharing. Olsaretti argues that although children are not public goods, they are socialized goods: societies do not exclude non-parents from the most important benefits created by parents but socialize some such benefits through unified public pension systems. The key difference between socialized and public goods is that the benefits of public goods are shared because of the nature of the goods (it can't be otherwise), whereas the fact that the benefits are shared is optional for socialized goods. Wherever there are unified welfare systems, children have to be seen as intentionally 'socialized goods', thus making parents eligible for support.

This line of argument is convincing but there is one significant worry. Although some of the benefits of well-raised and well-educated children are indeed socialized rather than public by nature (like pension systems), other benefits necessary for keeping the economy going, for example benefits created by well-educated young adults working for firms, are non-excludable. It would be morally unacceptable,

\footnotetext{
${ }^{19}$ It is worth noting that non-parents are also excluded de facto from some intrinsic benefits of parenting (e.g. the joy).
} 
impossible, or prohibitively costly to block non-parents from economic cooperation altogether. Hence, there is an important sense in which children are public goods. Olsaretti's analysis of intentionality and costliness also implies that non-parents have to pay on a straightforward public goods argument. This strengthens the pro-sharing case.

Let us now return to the two issues set out at the beginning of this paper whether business ought to shoulder the organizational costs of pregnancy and parenthood and contribute to family welfare policies (e.g. child allowances). Due to its focus on parents vs non-parents, the fairness discussion seems to imply that in ideal circumstances, in a just society, the business-related and nonbusiness costs of employees' children should be paid either by parents (on an anti-sharing view) or by both parents and non-parents (on a pro-sharing view), but not by firms. This means that, in ideal circumstances, fairness would not require firms to accommodate pregnant employees and parents nor shoulder the cost of their leave and would support the case for French businesses not to contribute to family welfare policies in the example noted above. Yet one may think that firms (primarily stockholders) are free-riding on the work done by families - mostly women - by hiring well-educated and well-raised employees. ${ }^{20}$ This kind of worry supports the calls for firms to pay the business-related and non-business costs of parenting. Should firms contribute on fairness grounds?

\section{Firms and the demands of cooperative justice}

In this section, we ask whether the efforts of parents generate obligations of fair play for firms. Do firms benefit from the relevant scheme of cooperation, which involves firms (or their members ${ }^{21}$ ) and parents? They benefit from new members of society. Those making or selling products for newborns and infants obviously benefit from people having children. In the absence of new children, these sectors would simply disappear. Besides, all firms require new generations for doing business. Firms need to hire new employees as older employees retire. Younger employees are usually paid lower salaries and often master new technologies, thus breeding efficiency and productivity gains. Businesses also need new customers for business growth or continuity and for shareholders to get some return on investment. The very idea of an investment requires some business continuity, which involves at the least some renewal of citizens. Whether population growth, rather than demographic stability or a slow decline, is desirable per se is another matter. The point is that some renewal of the population, i.e. well-raised children in society, is a positive externality for firms. Does this trigger obligations on the parts of firms towards parents? The answer depends on whether one supports a pro-sharing or an anti-sharing view. In what follows, we assume a rate of

\footnotetext{
${ }^{20}$ For versions of the complaint that capital takes unfair advantage of unpaid women's work, see Young (1990: 51) and Federici (2012: part I).

${ }^{21} \mathrm{We}$ use the word 'firm' to identify those people who are involved in and benefit from its activity: shareholders, managers and employees. See Section 4.2 for an overview of various accounts of the firm and how they connect to our argument on parental justice. Note, as suggested above, that firms and non-parents are not non-mutually exclusive categories and that firms may stand for a group that includes both parents and non-parents.
} 
population renewal, be it growth, ${ }^{22}$ stability, or slow decline, in which the overall gross benefits from there being additional children exceed the costs.

\subsection{Firms' obligations in parental justice}

From the anti-sharing point of view, the requirement that the cost of children should be borne by parents and procreators seemingly excuses non-parents as well as firms from making a contribution. Rakowski rhetorically asks: '[W]ith what right can two people force all the rest, through deliberate behaviour rather than bad brute luck, to settle for less than their fair share?' (Rakowski 1991: 123). Assuming a just background distribution, these unfairly burdened 'others' may be thought to include firms which incur business-related costs and, if made mandatory by states, non-business ones. At the very least, parents cannot expect a contribution from firms, but according to the more extreme versions of the anti-sharing view (Rakowski 1991), parents should compensate firms for the negative externalities - the gross costs - that firms incur. The fact that firms also benefit from procreation and child-rearing is, on Casal and Williams' view, irrelevant: it is morally permissible free-riding. ${ }^{23}$

The pro-sharing perspective we developed above offers a radically different picture. First, it is possible to draw on the public goods argument for cost-sharing, because the condition of non-excludability from some benefits associated with children is met. Additional members of society generate public goods because firms (or their members), just like non-parents, cannot be excluded from enjoying some goods of new members such as well-raised, law-abiding employees and consumers, i.e. prohibiting some firms from hiring skilled employees, or hiring altogether, or indeed selling to customers might seem practically impossible, prohibitively costly, or morally impermissible.

Besides meeting the requirement for fairness on the side of children, the two necessary conditions on the parents' side for the principle of fair play to apply seem also to be present. While parents' intention to raise good consumers is dubious, there is non-altruistic intentionality in so far as kids are raised, in part, to be future employees. In addition, the practice is relevantly costly to parents and made even more so by firms: parents incur gross costs. Parents' practice imposes gross costs on firms too. Thus, some benefits associated with children as employees are public goods, and the costs borne by parents and incurred by firms ought to be shared.

One might deny that we cannot permissibly exclude firms from these benefits and hence deny that the public goods argument applies. Even if that is right, the socialized goods argument still supports pro-sharing if (which certainly holds in our non-ideal world) new members are socialized to the benefit of firms. ${ }^{24}$ Firms take advantage of a workforce (as 'human resources') which is increasingly tailored to their needs - one has only to consider the number of unpaid

\footnotetext{
${ }^{22}$ This may not hold in the real world, given negative environmental externalities flowing from additional children. See for example Meijers $(2016,2017)$.

${ }^{23}$ The anti-sharing camp may support distribution from firms to parents for distributive justice reasons. Taxing firms may (but not necessarily) serve as a proxy for taxing those who are well-off. The reason for this distribution would be egalitarian concerns, not concerns regarding parental justice.

${ }^{24} \mathrm{This}$ is not to say that we welcome the fact that businesses have this kind of influence.
} 
internships that students must do, the increasing weight of business studies in higher education and research as opposed to humanities, and employment in firms as a stated aim for public education systems. All of this suggests that the needs of firms partially shape the education agenda. This happens through higher education, recruitment expectations, and in the home, tailoring future employees to the needs of businesses. This makes the availability of a qualified workforce not just a positive externality; the workforce is also (partially) socialized to meet the needs of businesses. The productive system is collectively shaped to make firms benefit from it; this mirrors in the productive sphere Olsaretti's view of the pension system as a socialized form of benefits gained from children. Hence, the intentionality and costliness conditions being met, Olsaretti's pro-sharing argument based on the claim that children are socialized goods applies here as well. This reinforces parents' claim that firms should share in the costs. Businesses should therefore share some employees' 'production costs', either on a public goods argument or, minimally, on the basis of the socialized goods arguments. That is to say, firms should pay for some of the non-business and business-related costs of children. Firms should share these costs for all children, not just for the children of their staff, because all firms benefit from the future workforce in general but they do not benefit from the children of their workforce in particular.

How much firms should contribute, compared with parents, non-parents and society as a whole, is not easy to establish. Defenders of pro-sharing are not explicit about how the costs of universal welfare state provision for children should be distributed: should all beneficiaries contribute equally or according to some kind of proportionality principle? We propose a beneficiary pays principle: the costs should be distributed in proportion to how much actors - firms included - benefit. In other words, the ratio of gross benefits to costs should be equal for all participating members in the cooperative scheme: parents, firms and society as a whole. ${ }^{25}$ In practice, it may be difficult to assess how much and in what ways parents, non-parents, firms and society as a whole benefit from additional children in the productive and redistributive schemes of cooperation; what is clear, however, is that since all firms benefit from the workforce, all firms should pay.

Once the gross benefits and associated contribution of each group is established in each scheme, in particular that of firms in the productive scheme of cooperation, one further question arises: how should businesses' contribution be allocated across firms? While firms benefit from current and future consumers, we do not count sales as benefits that trigger an obligation to contribute: the reason for this is, as we have noted earlier, that the pro-sharing view (at least on Olsaretti's account) requires parents to intend to create benefits in order for them to be entitled to compensation (even if it does not require them to intend to benefit others). And it is not likely that parents intend to turn their children into consumers of products, so the obligation to subsidize parenting cannot be ascribed to firms on

\footnotetext{
${ }^{25}$ This is similar to the principle advocated by De Briey and Van Parijs (2002) regarding linguistic justice as cooperative justice: in their view, cooperative justice requires that the ratio of the gross benefits to costs of some learning the dominant language be equal for all.
} 
the basis of their receiving these benefits. ${ }^{26}$ Parents do intend to raise wellfunctioning employees, and this grounds their claim to cost-sharing. Hence, we venture that the number of employees is a proxy for the relevant benefits of each firm; firms' contribution to the costs of children should therefore be set as a percentage of their payroll, rather than of sales or profit. ${ }^{27}$ Besides, bigger corporations may influence the higher education agenda and benefit from it more than smaller firms, so perhaps they should pay comparatively more.

Firms' contribution to covering the cost of children can be illustrated by referring to the cost of education, which includes background justice costs (e.g. citizenship skills), other morally required costs (e.g. skills needed to pursue life plans), morally non-necessary beneficial costs (e.g. an expensive art education, private lessons), and socially required costs (e.g. business training or internships). Background justice tells us how much parents earn after tax and transfers as their fair share, as well as whether some costs of education are required as a matter of background justice. Parents create, either through individual choice or social processes, further necessary and non-necessary educational costs. Leaving aside the costs of background justice, fairness says that all citizens (taxpayers), parents (and students), and firms should share all other costs of education in proportion to how much they benefit, for example as citizens benefiting from the public policies funded by extra tax raised from higher earners, as firms benefiting from a tailored workforce, and as parents and students benefiting from having the skills needed to pursue their life plans and the prospect of a better position on the job market.

While the example above focuses on one particular cost of children that is primarily borne by parents and should be shared by firms (non-business costs), firms' joint contributions (along with the contributions of other groups, such as taxpayers) should also be used to cover the gross costs of children incurred by firms (business-related costs). Firms should not pay for their employees' pregnancies (and parenthoods), which could indeed hit some sectors more than others, such as those with relatively few female employees (e.g. the construction sector), or may hit firms with fewer employees relatively hard, while the consequences might go unnoticed in bigger firms. Hence, fairness requires compensating firms for the direct costs they incur when their employees are pregnant or become parents. Compensation should be made available by all firms (and other beneficiaries of the scheme) collectively. This is an interesting implication of our account: all the costs of businesses regarding their employees becoming parents are acknowledged as an unfair burden of the scheme that

\footnotetext{
${ }^{26}$ If one can plausibly argue that parents do intend this, one would further strengthen the pro-sharing view.

${ }^{27}$ We propose the use of 'human resources', as measured by the payroll, as the normative criterion for how much firms, and hence all their members, benefit and should contribute. Whether a payroll tax best achieves the aim of having members of a firm contribute in proportion to the benefit they receive is another matter. Economists suggest that the question of whether capital or labour shoulder a social contribution set as a percentage of salaries in the long term depends on the circumstances. Some end-beneficiaries tax might be thought to be more appropriate than payroll tax, but devising how much an individual benefits from human resources remains to be determined. Thus, we leave open the question of which fiscal arrangement would best achieve the aim of having those who benefit from firms contribute.
} 
should be compensated for. The form of the compensation, whether a direct financial contribution or some free support from jointly funded HR consultancies, could be left to businesses to decide on the basis of their self-assessed needs and a realistic assessment of their costs. While this may be irrelevant for bigger firms, it may be of significance to small businesses.

In sum, fairness requires that firms bear some of the costs of children, both business-related and non-business costs, as beneficiaries of a productive scheme of cooperation. We suggest that funding should be made available by way of contributions from all firms, in proportion to the size of their payroll, and with a comparatively higher contribution, say a higher of percentage of the payroll, from bigger corporations than smaller businesses. Furthermore, business-related costs should not be borne by firms individually whenever their employees become pregnant or a parent: firms should be fully compensated by other firms and scheme beneficiaries for the costs they incur.

Returning to the two issues set out at the beginning of this paper, in ideal circumstances, a pregnant woman no longer able to perform heavy-duty tasks should indeed have part of her costs of pregnancy covered, including her leave, though not directly by her employer but via a scheme jointly funded by firms and taxpayers; or she should be accommodated, and the costs incurred by her employer should be covered by this same scheme. Similarly, in ideal circumstances, the French businesses mentioned at the outset should contribute to the non-business costs of children yet have the costs they incur taken care of collectively. This ideal model is in fact close to the model that existed in France prior to the policy change (yet in non-ideal circumstances) and in which firms were required to contribute to the non-business costs of children via a payroll tax-funded family policy, one difference being that business-related costs besides leave should also be jointly covered.

\subsection{How do firms matter?}

We would like to conclude this part of the paper, which focuses on the principle of fair play, by setting out some of the key features of this account and how it differs from current parental justice discussions. First, the argument from fairness set out above refers to 'firms' as a way of delineating a subgroup of individuals who draw particular economic benefits from parents raising children and who should contribute to shouldering the cost of children. Taxing firms as legal entities is justified if and in so far as doing so is either a reliable proxy for, or is necessary for, taxing the individuals who benefit. ${ }^{28}$ According to this view, a corporate duty to contribute through payroll tax is instrumental to and justified by individual duties. This does not imply that this is the only possible, or most efficient, scheme that could achieve this. Besides, this proposal is compatible with two main views of the firm: that the firm is a nexus of contracts and that it is an agent. If one sees firms as a nexus of contracts between factors of

\footnotetext{
${ }^{28}$ Payroll taxes may not be shouldered by all stakeholders in proportion to the benefits they receive from the firm. For a critical discussion of corporate (rather than payroll) tax as a means of taxing shareholders, see Avi-Yonah (2004).
} 
production (Jensen and Meckling 1976; Fama 1980; Fama and Jensen 1983), 'firms' simply refers to those members involved in the networks of contracts: shareholders, managers and employees. If one sees the firm as displaying the necessary features of agency - interests and an ability to make a judgement and to act on interests (List and Pettit 2011) - firms' rights, and presumably duties, can still be defined by reference to the interests of individual agents (Pettit 2014; Orts and Sepinwall $2015)$ - i.e. firm members. Some see firms instead as personal agents with the same rights and duties as human beings (but List and Pettit 2011). On this view, firms can appear on the list of contributors to and beneficiaries of society's scheme of cooperation, just as human beings do. Yet one need not, implausibly in our view, claim that firms are like individual agents in order to be able to argue that they have duties, including the duty of fair play.

Second, the pro-sharing normative claim that firms (or economic beneficiaries) should pay has some practical implications that differ from Olsaretti's claim that taxpayers should pay (or is more specific about why and how much various taxpayers should contribute). One difference is that 'surfers', or those people less involved in economic activity but who may be included in the general-purpose tax base, ought to contribute less to the costs of children than actors who heavily benefit from economic cooperation. Firms and their members, after all, profit from the productive system made possible by procreation and parenthood in all the ways the proverbial surfer does, and more. Hence, they should contribute more because, unlike surfers, as firm members they make use of an educated workforce.

Another important distinction is that any international shareholders of a company ought to contribute: they will if firms are taxed, but not if only taxpaying citizens pay. While a focus on redistribution and taxpayers implicitly frames parental justice as a domestic debate, the cooperative approach allows, in effect, for non-territorial consideration of contributions to parental justice, which may become increasingly relevant with the rise of multinational enterprises. In sum, this paper's proposal of considering firms completes the view that nonparents should pay because they benefit from unified pension systems. It shows that various subgroups benefit in different ways from there being additional children and that these groups need not be limited to a set territory.

Yet one might argue that there is a significant difference between how individual persons and firms benefit from the renewal of generations. Persons are likely to benefit in the future from the children whose raising they are contributing to (e.g. through pensions), but firms do not necessarily profit from the children they are subsidizing now: by the time the children become economically active and employable, these firms might no longer exist, or at least the stakeholders in the firm will probably have changed. There are several possible replies to this worry. First of all, we might point out that it is the practice of generational renewal that firms are profiting from. Second, we might point out that direct reciprocity is not what matters to begin with: contributing to a scheme of cooperation over time is what is important, and - as with pension systems, given that we contribute to our grandparents' and perhaps even greatgrandparents' pension as well - indirect reciprocity seems a more plausible ground of intergenerational justice (Gosseries 2009, but see Heath 2013). 
The former analysis is explicitly pro tanto: it is set against a just background and focuses on considerations of fairness only. This has two implications: first, some may argue that in just circumstances families already receive support. This may be for simple distributive reasons or for reasons related to making sure the child's claim to a fair share is met. We agree that there may be other social justice-related reasons to support parents, and offer one consideration for additional support, setting out who should contribute and to what extent on cooperative grounds. Second, an all-things-considered assessment of firms' contribution will also depend on how other, possibly competing, values figure in the considered society (e.g. efficiency). ${ }^{29}$

In addition, this analysis applies in ideal circumstances, assuming cooperators' full compliance with the principle of fairness. In non-ideal circumstances, parties might opt out of cooperation or take advantage of cooperation by dodging their fairness obligations. A parenting tax on business may lead some corporations to relocate to more favourable - yet possibly unjust - countries. ${ }^{30}$ If so, in non-ideal circumstances, taxpayers may be a better tax base than businesses, to avoid the relocation of local firms that a parenting tax would otherwise put at a competitive disadvantage. These considerations would certainly have some weight in an all-things-considered account of the distribution of the costs of children in non-ideal circumstances, but we maintain that firms should contribute in ideal circumstances.

Finally, debates on parental justice have mainly been framed in terms of cooperative justice in ideal circumstances, and this is the debate we have pursued so far. This does not provide an immediate answer to the question of what should be done in France, and indeed many other countries, if one believes, quite sensibly, that they do not reflect ideal circumstances. Besides, the principle of fairness is controversial and some may question the normative weight of duties of fair play and the requirement of contributing to benefits created through the choices of others. Taking stock of both limits, we explore an account that relies on weaker assumptions regarding compliance and background justice and on a less controversial principle. Thus, we now turn to another set of reasons why firms seem to be an important site of parental justice in non-ideal circumstances: for the sake of equal distribution of work opportunities and access to social positions.

\section{Equality of opportunity, parenthood and firms}

In this section, we explore a ground for requiring a contribution from firms to the costs of children in non-ideal circumstances. We will continue to assume that firms incur costs if an employee decides to procreate and parent. We argue that there are equality of opportunity-based reasons to compensate individual firms, and - drawing partially on the arguments given above - we argue that firms should collectively cover at least part of the cost of this compensation. Relaxing our assumption about background justice and full compliance, we take aim at wrongful statistical discrimination and

\footnotetext{
${ }^{29}$ Efficiency considerations may help when choosing between equally fair schemes. If the proposed scheme were prohibitively costly, however, whether it should be maintained all-things-considered depends on the ordering of fairness and efficiency in the considered society.

${ }^{30}$ For a helpful account of forms of tax avoidance, see Dietsch (2015).
} 
ask whether justice in non-ideal circumstances also requires firms to contribute in the domain of parenthood and procreation.

This fair equality of opportunity (FEO) argument is independent of the argument from fairness presented above and may win over both those persuaded and those not persuaded by the argument from fairness. However, whether or not one accepts the pro-sharing view defended above will partially determine one's stance on the question of the extent to which we have reasons, all things considered, to make firms pay for the costs of realizing FEO that result from parenthood and procreation. The reasons for the financial transfers to and from firms proposed in this section are justified not because they equalize benefits to costs ratios but by virtue of the effects they have on the distribution of social and economic goods in society as a whole in nonideal circumstances, specifically in terms of equality of opportunity. First, we set out the various ways in which procreation and parenting affect equality of opportunity. Second, abstracting from the macroeconomic consequences of compensating firms, we argue that equality of opportunity speaks in favour of compensating firms from a fund that firms fund collectively for the businessrelated costs they incur when their employees decide to procreate and parent.

\subsection{Parent-related inequalities of opportunity at work}

Equality of opportunity plays a different role in different theories of justice. In some theories of justice, it is one of several principles at play. For example, Rawls combines it in his theory of justice with the liberty principle and the difference principle. In other theories, such as the equality of opportunity for welfare view, it is the central principle of (luck egalitarian) justice (e.g. Arneson 1989), although on such views, justice counts as one value among others. We will focus on the particular interpretation offered by Rawls, but much of what we say will also be relevant to other views which assign an important place to equality of opportunity. Rawls describes the principle of fair equality of opportunity (FEO) as follows:

[T] hose at the same level of talent and ability, and have the same willingness to use them, should have the same prospects of success regardless of their initial place in the social system, that is, irrespective of the income class into which they are born. In all sectors of society there should be roughly equal prospects of culture and achievement for everyone similarly motivated and endowed. The expectations of those with the same abilities and aspirations should not be affected by their social class. (Rawls 1971: 73) ${ }^{31}$

FEO is violated if and only if: (a) two groups of people have different chances of attaining a certain social position due to a certain feature and (b) this feature is not able to justify differences in opportunity. In what follows, we focus on equality of opportunity between different categories of people participating in the labour market: men vs women (childless adults), fathers vs mothers (parents) and caregivers vs non-caregivers (all adults). ${ }^{32}$ While the categories may overlap, examining them

\footnotetext{
${ }^{31}$ Rawls refers to 'social class' here, which can easily be supplemented with 'gender'.

${ }^{32}$ Similar categories of perceived employability are used by Kmec et al. (2014).
} 
separately allows us to distinguish between disadvantages resulting from different positions and shows us where disadvantage clusters. If some features can explain yet not justify unequal work opportunities between the groups mentioned above, we are dealing with unfair inequality of opportunity. We argue that such features exist and that some result from the real or perceived burden of procreation and parenthood for firms.

FEO between women and men who are not parents (type I). Let us first compare the situation of men and women who are not parents. Employers are often more keen on hiring or promoting men rather than women, which the term 'glass ceiling' reflects. The explanation for this is complex, and a full picture of why this happens will no doubt have to look at cultural aspects, psychological aspects (e.g. study in-group bias), etc. One clear mechanism at play is statistical discrimination ${ }^{33}$ against women: employers may prefer to hire a man rather than a woman because women are statistically more likely to be less involved in work at some point in their lives, a situation which firms perceive as a burden.

Two facts are crucial here. First, the vast majority of women give birth at some point in their lives, even in countries where fertility levels are rapidly declining. The statistical likelihood that women will be unavailable for work for some amount of time is high. The second fact is that women generally take on the lion's share of parental work (Becker 1981: 74; Ferguson 2013), and there is evidence that the gendered division of labour increases after childbirth (Yavorsky et al. 2015). Many women start working part time or become less available to work in line with unpredictable and demanding schedules. Men often rely (statistically speaking) on their partner for the majority of care work. ${ }^{34}$ Hiring a man rather than a woman decreases the probability of hiring someone who will need time off for parental duties. Importantly, this is a different kind of fact than the fact that women give birth to children: it is a cultural practice, which varies across countries - Scandinavian countries appear much more egalitarian in this respect than many continental and Southern European countries and is subject to change. The fact that women are the primary caregivers is not unavoidable, but in many parts of the world as it is, if an employer wants to avoid hiring (or promoting) someone who may in the future shift their focus from work to the domestic sphere, gender remains a reliable proxy.

These two facts, and the (perceived or real) costs for firms associated with an employees' increased focus on the domestic sphere, lead to statistical discrimination between men and women. Key to statistical discrimination is that, regardless of what choice an individual woman will make, the behaviour of the group she is a part of partially determines her chances of getting a certain job.

\footnotetext{
${ }^{33} \mathrm{We}$ use a non-moralized definition of statistical discrimination. Lippert-Rasmussen defines statistical discrimination as follows: '[I]ndividuals treat people differently in part because they believe that their membership of a certain socially salient group is a good statistical indicator of other things they are interested in e.g., insurance companies charge young men higher premiums for care insurance because of the (true) belief that young men are more likely to be involved in traffic accidents than are other people' (Lippert-Rasmussen 2014: 88). Statistical discrimination is not always wrong, but on a Rawlsian account it is wrong if it leads to a violation of equality of opportunity. This is not uncontroversial; see, for example, Arneson (1999).

${ }^{34}$ See, for example, the 2015 data from the US Bureau of Labor Statistics Annual Time Use Survey (2015), Labor: http://www.bls.gov/news.release/atus.t01.htm.
} 
Belonging (or not belonging) to a group with a higher probability of pregnancy and of acquiring care duties is a feature that accounts for unequal work opportunities for men and women (even before they are parents). The high statistical probability that women will become pregnant and be primary caregivers creates unequal opportunities on the labour market for men and women regardless of whether they plan to procreate. Even if we assume that an individual's wish to parent and procreate can legitimately affect her work opportunities, fair equality of opportunity is still violated: people with exactly the same talent and motivation have differential opportunities. Levelling the costs of hiring someone who might procreate and parent would take away a reason that leads to such statistical discrimination.

FEO between fathers and mothers (type II). Let us now turn to the category of parents and compare the situation of fathers and mothers. Let us define parental caregivers (caregivers for short) as those parents who actually take on a substantial part of the care duties. The worries noted above are relevant for people without children. But once they have children, there are differences in opportunities between fathers and mothers on the labour market. Again, there is a probabilistic concern: when an employer has to decide between hiring or promoting a father or a mother, opting for the father is a reliable proxy for picking the worker who is not a caregiver and who prioritizes paid work over the domestic sphere. Belonging to a group with a higher statistical probability of having care duties is a feature that explains unequal work opportunities for fathers and mothers. Mothers who are not caregivers have fewer opportunities for work (or promotion) than fathers who are also not caregivers. And mothers who are caregivers have fewer opportunities than fathers who are also caregivers. ${ }^{35}$ The principle of equality of opportunity is again clearly violated: people with exactly the same care duties should have the same opportunities. Going by probabilities here is not permissible. Levelling the costs of hiring a parent, male or female, would take away the rationale for such statistical discrimination between fathers and mothers.

FEO between caregivers and non-caregivers (type III). Finally, let us compare adults who are caregivers and adults who are not. We define a caregiver as an adult who shoulders a significant part of the care work in raising children. Suppose an employer has to decide between promoting three equally talented employees: person $\mathrm{A}$, a father of two, or person $\mathrm{B}$, a mother of two, or person $\mathrm{C}$, who is not a parent. ${ }^{36}$ The employer knows the following facts: person $\mathrm{A}$ is not a caregiver as

\footnotetext{
${ }^{35} \mathrm{Kmec}$ et al. show that there is a 'fatherhood bonus': 'Fathers are perceived as being more employable than all other men and women.' Mothers (and female caregivers) are perceived to be less employable, as noted by Kmec et al. (2014: 457).

${ }^{36}$ It is quite plausible that women suffer a greater setback than men if they take on the role of the primary caregiver. Although data on differential career success between primary and secondary caregivers is hard to find, Janet Waldfogel's work on the family gap is suggestive. She points out that women with children tend to have significantly lower salaries than women without. For women, there is a child penalty (Waldfogel 1997: 209; see also Budig and England 2001), or - more appropriately given that this penalty does not exist for men, who get a 'fatherhood bonus' in terms of wages - a motherhood penalty. Given that among people who are parents, someone's gender is a reliable proxy for whether the person is also the primary caregiver, it seems that those who are perceived as caregivers are indeed disadvantaged (or at least that women who are perceived as primary caregivers are worse off in terms of career prospects than women who are not perceived as such). Waldfogel points out that paid maternity leave - which
} 
he is married to a stay-at-home wife who does all the care work. Person B's husband has a career of his own and she does most of the care work. Person $C$ has no parental care duties. A and $\mathrm{C}$ are not caregivers, while $\mathrm{B}$ is. Let us assume that $\mathrm{B}$ does less at work than $\mathrm{A}$ and $\mathrm{C}$, in spite of having equal talents. Does the fact that person $\mathrm{B}$ decides to do more work around the house and become less involved at work justify that the employer favours A or C over B? In other words, does the feature of being a caregiver justify B having fewer work opportunities?

FEO is violated if people's chances are influenced by the statistical probability that they may shift their focus from the workplace to the domestic sphere. It is less clear that Rawlsian equality of opportunity rules out unequal opportunities for people who focus on work and people who decide to shift their focus towards care work. For Rawls, if people have the same options available to them, it is justifiable that opting for a different path leads to different career opportunities. Equality of opportunity aims to ensure that people who are equally motivated and equally talented have equal chances. If someone decides to shift their focus to the home, although that person is still equally talented, (s)he is now less motivated, so, on this view, it is not unfair that (s)he has fewer opportunities. There are several possible objections to this conclusion. Let us point to three strategies that can be used to argue that in such cases, FEO as properly understood is violated.

First, perhaps the decision to parent should not influence peoples' work opportunities, because of the important goods at stake in parenthood. For example, Jonathan Quong (2006: 62) thinks it is unjust that members of different religions have unequal work opportunities because of the demands their religion places on them. If procreation and parenting are similarly important (e.g. Brighouse and Swift 2014; Meijers 2016), there may be good reasons to accommodate this plan without compromising equality of opportunity regarding work positions (strong type III).

Second, such a strong kind of equality of opportunity between caregivers and noncaregivers could also be defended by emphasizing that the decision to become a caregiver is likely to have been the consequence of gender socialization. Unequal motivation justifies unequal opportunities because people are to be held responsible for their conceptions of the good life, but perhaps not all women should be held responsible for preferences shaped by gender socialization, or 'stunted ambitions', as Arneson (1999) puts it. Others reply that this consideration amounts to a denial of women's agency. Mason asks us, for example, to imagine a 'career sacrificing mother' (Mason 2000: 234) who really wants to shift her focus from the workplace to care work. Saying that she has to be compensated for doing what she wants to do casts doubt on the autonomy of her decision and denies her agency. But this cannot be right: in Mason's example, the careersacrificing mother takes the decision voluntarily and reflectively endorses it (Phillips 2006: 19). Whether inequalities resulting from gender socialization violate FEO raises complex questions for egalitarians of all stripes.

While gender socialization is an example of gender injustice, we do not think that in the case of the career-sacrificing mother FEO is violated, because we believe that

causes fewer women to drop out of the labour market once they have children - decreases the family gap (1998: 138). 
she reflectively endorses this aim for herself. We should not expect that FEO will solve all gender injustices. Like Mason, we think that cancelling out the effects of gender socialization completely, so that women and men do not have radically different preference structures, is not possible without a change in ethos. We should, of course, try to offset some of the disadvantages that disproportionally fall on women due to gender socialization and make sure that we avoid implementing policies that further entrench the gendered division of labour. This discussion is, of course, brief, and much more needs to be said about this complex issue.

The third route is to deny that women have the same choices as men, regardless of the value placed on parenting. For this route, one could assume that choosing to be a caregiver may legitimately affect someone's career. One may note that the 'marriage market', combined with the career cost of parenting, incentivizes women to prioritize the domestic sphere: the pool of compatible partners would be limited for women who prioritize their career instead of the domestic sphere, because although there are many women willing to support their partner's career at some cost to their own career, there are far fewer men willing to do this. ${ }^{37}$ This makes it harder for women to combine family life and a successful career than for men with the same preference structure. We should not only look at opportunities for activities considered in isolation (e.g. to parent, to pursue a career, to find a partner), but at opportunities for combinations of activities: people with similar preference structures and equal talents should have equal opportunity sets. If parenting comes at some (even legitimate) cost to a career, the gendered distribution of preferences regarding the prioritization of career over family makes it harder for women to combine a successful career and family life (weak type III). This account of structural discrimination (not statistical discrimination) is a plausible and a normatively less demanding reply. On our view, such structural discrimination constitutes a violation of FEO.

To conclude, we have argued that statistical discrimination between men and women, and between fathers and mothers, violates FEO. We have also argued that discrimination between people who are actually less efficient workers due to deciding to shift their emphasis to care work is more complex. Can people be held responsible for being less effective workers because they take on parental care work? We think that inequality in the choice set of different types of people does render differential treatment a violation of FEO (weak type III), and we believe that there are good reasons to try to offset some of the effects of unequal preference formation - but perhaps not fully. Overall, firms' descriptively discriminatory practices in hiring and in promotion violate FEO in various ways. We now turn to what could be done about it.

\subsection{An insurance scheme to equalize work opportunities}

If you believe that parenting duties should not affect work opportunities and that this is a case of discrimination because of the value of parenting or because of

\footnotetext{
${ }^{37}$ This is the case of Bob and Ann proposed by Andrew Williams (2002: 30-32). We should of course note that these worries play on the heterosexual wedding market, for same-sex couples this may look different.
} 
socialization (strong type III), a pregnant mother or a parent who needs time off work should be fully compensated for their temporary loss of salary. But if one resists the idea that equality of opportunity should apply to caregivers and noncaregivers, unequal opportunities (between men and women, whether parents or not) of types I, II and III (weak type) nevertheless provide reasons to compensate firms for all costs incurred. If the efficiency loss employers experience (or, perhaps, expect) is cancelled out, the incentive to hire or promote men rather than women disappears. ${ }^{38}$ The reasons for statistical discrimination between men and women who are not parents (type I) and between fathers and mothers (type II) will disappear. Unequal opportunities of weak type III will also be levelled. If prioritizing family no longer affects firms (and careers), the requirement that one parent makes career sacrifices will disappear, and alongside this, the reasons for preferring a career-sacrificing partner will disappear as well. Women's profile as workers will not matter anymore on the wedding (or partner) market, providing that women and men willing to pursue a career and raise a family have similar combined opportunities to do so.

Our institutional proposal is this: we should create a fund which will compensate firms for the business-related costs of children they incur (we return to who pays below). The goal of this fund is not to make it cheaper for firms to hire women rather than men, but rather to level out the (perceived) cost differential between men and women. It aims to remove the rationale for statistical and structural discrimination and to undermine gender as a reliable proxy for productivity (or if it was never a good proxy to begin with, this is a way to cancel out perceived productivity difference). The wedding market will simultaneously be protected against ripples from the work sphere.

Of course, the question is to what extent this can realistically be achieved. In the case of low-skilled jobs, compensation might be easy. At a high level of management, there might be no other option than for employees to be available 75 hours a week or for long trips abroad. Compensating firms for the loss incurred because one employee has to pick up the kids from school at five, and is unavailable at weekends, may not always be possible. Of course, whether such jobs exist and how many of them there are is an empirical question; to what extent having positions which require such schedules and demands is desirable is another one.

Are there no better ways to promote equality of opportunity? Although our scheme casts the net a bit wider than gender discrimination (type III discrimination), policies aimed at tackling gender discrimination often address the same issues. The obvious alternative to our proposal is equal parental leave (Brighouse and Wright 2008). This would resolve most, but not all, differences:

\footnotetext{
${ }^{38}$ One might worry that the incentive to discriminate is only taken away if women will be employed somewhere else, but that if firms as a group start excluding women, costs could be kept down. Although this is a possible worry, we think that the marginal increase in contribution to the fund for an individual firm for appointing a woman is so low, that this will insignificant. Only if firms collectively and in a coordinate fashion agree to discriminate against women would such discrimination continue to be beneficial, although certainly large-scale exclusion of women on the labour market would not be beneficial.
} 
women also go on pregnancy leave. This might be insignificant, but if not, proposals for obligatory equal parental leave may be easily amended to eliminate it, requiring that fathers take 'pregnancy leave' as well. Not, of course, because the father needs to recover physically from giving birth but to eliminate an advantage of hiring men rather than women. One may suspect that, depending on how the father spends the additional weeks off, it may have further beneficial effects, e.g. if fathers spend this time doing housework and care work.

Our proposal may be thought to have at least one advantage: it offers a way out of the feminist liberal-egalitarian trilemma sketched out by Ingrid Robeyns and Anca Gheaus (Gheaus and Robeyns 2011). They argue that in designing parental leave policies to promote gender equality, we are confronted with three often competing goods: parental care, individual choice, and gender justice. ${ }^{39}$ Devising forced equal parental leave, as proposed by Brighouse and Wright (2008), compromises individual choice and, under some circumstances, the good of parental care. Less demanding proposals, like allowing men to take longer paternity leave, fail to realize the good of gender justice, because, among other things, this will fail to address the deeply entrenched gendered division of labour. Our proposal performs well in reference to the three liberal egalitarian feminist values. Compensating firms for the direct costs that they incur if their employees have children promotes gender equality without compromising on parental care or on the freedom of choice of individuals. The solution proposed here does not require people to take forced leave, and it does promote gender equality. ${ }^{40}$ The quality of parental care may not be improved - although perhaps redistribution that benefits parents will have this effect - but nothing suggests it would be negatively affected.

This proposal also addresses Alstott's concern that workplace regulations favouring women - say granting paid parental leave - may worsen gender discrimination in the workplace. It is economically rational, Alstott points out, to avoid hiring people who are statistically more likely to create costs (Alstott 2004: 154). Employers could avoid the costs of parental leave schemes simply by not hiring women. This is why Alstott prefers caretaker accounts, i.e. ways to enhance women's competitiveness (through, for example, vouchers for parents to buy childcare or education), rather than making the hiring of women a potential economic liability. This is an important worry: we should not assume that workplace regulations aimed at making the workplace more family-friendly will improve the position of women. Our proposal addresses this worry: it is workplace regulation that evens out the employment costs of men and women.

Our proposal certainly does not solve all of the problems. We have already mentioned the practical difficulty of devising adequate compensation for firms. The scheme proposed would have to be quite elaborate, and it faces substantial

\footnotetext{
${ }^{39}$ Gheaus and Robeyns (2011) propose a different solution. Ways of promoting equal parental leave are in no way incompatible with what we have proposed here. It may very well be the case that the best way to promote equality of opportunity will involve a combination of different policies.

${ }^{40}$ This proposal does not, by itself, even out the gendered division of labour. To do this, additional policy changes are necessary, e.g. Gheaus and Robeyns' 'defaults proposal' (Gheaus and Robeyns 2011). Our proposal does not contribute to the entrenchment of gender norms either; rather, a heightened and improved position of women on the labour market hopefully contributes to the weakening of gendered expectations.
} 
epistemic problems. For example, how do we calculate the loss for a firm caused by one particular individual who struck her work-family balance in way $\mathrm{X}$ before she had children but in way Y once she has children? Yet such a precise assessment might not be necessary to counteract the statistical discrimination that women face: a rough approximation may serve equally well to make it economically rational for employers to become indifferent about whether they hire a man or a woman.

Many other questions about implementation and worries about side effects arise. For example, one might ask who this fund should be managed by. By firms, or by the state? This question does not have a principled answer: it depends on which route would best fulfil the objectives of the scheme as well as other considerations of justice. We cannot get into these questions here, but we do want to note that when deciding whether we have all-things-considered reasons to implement our proposal, more would have to be said.

What we have shown so far is that there are reasons to compensate firms for their incurred costs of parenthood and procreation in order to promote FEO. Does this conclusion not go against the conclusion that firms should pay part of the costs of parenthood and procreation? This depends on who should pay the compensation (Issacharoff and Rosenblum 1994: 2218-2220): firms, parents or society as a whole? How one answers this question all things considered depends partially on whether one accepts the pro-sharing argument made in the previous sections and believes it carries over in non-ideal conditions. If firms have a fair playbased obligation to pay for (a part of) the costs of parenthood and procreation, paying into this fund might be one way of doing so.

However, other arguments - independent of fair play - also support the conclusion that firms should pay. These arguments might be endorsed both by those who hold a pro-sharing position (as additional arguments) and by those who hold an anti-sharing position (as independent arguments). Let us mention two such arguments. The first appeals - and depends on - the idea that statistical discrimination is wrong. The agent acting wrongfully should not make doing the right thing dependent on others incentivizing them. The need for compensating firms results partially from a firm's engagement in wrongful discrimination. If one believes that firms are important agents of justice (O'Neill 2001), one might, drawing on Cohen's (2000) objection to incentives, argue that it is unfair to ask society to pay for incentives to get firms to do what they ought to be doing anyway, that is, respecting FEO.

In any case, firms are an important site of justice, and their hiring decisions and policies are supposed to advance FEO. If the proposal takes the form of an obligatory insurance scheme contracted into by firms, with the level of contributions set, for instance, as a percentage of each firm's payroll, firms will be paying to incentivize themselves to do the right thing. Sharing the costs in this way among all firms seems a good way of correcting the incentive structure without having parents or society pay for firms' wrongful discrimination. The goal of the scheme is not to make sure firms comply with their duties but to ensure that the object of this particular duty of firms is achieved: fair equality of opportunity. On such a view, we are self-incentivizing firms rather than compensating them for the business part of the cost of children. 
The second reason appeals to general distributive justice reasons in non-ideal circumstances. Compensating companies for the costs resulting from their employees' decisions to procreate and parent may be anti-redistributive, because it involves spending public money to sponsor businesses ${ }^{41}$ and, indirectly, the wealthiest people in society, at least in our world, where the ownership of companies is concentrated in the hands of a few. Making firms pay instead might, if companies internalize the cost and do not charge it to employees or consumers, be a redistributive measure. We agree with all three reasons, but only one needs to be agreed with to accept the conclusion that firms are liable for at least a part of the costs of the proposed scheme. Only someone who denies both the pro-sharing and the two additional arguments might conclude that society as a whole should pay compensation for the costs of employees' procreative and parental decisions.

The FEO arguments for an insurance scheme still have to be balanced against other justice considerations. Thus, whether it should be firms or society as a whole that should pay, all things considered, depends on which way would serve the overall interest of justice best, including, along with equality of opportunity, the fair distribution of primary goods. If, say, this parenting tax on firms were to decrease firms' competitiveness and lead to a great loss of jobs (a question raised in the French case discussed above), or if raising money from business for the scheme were prohibitively inefficient and compensating firms made impossible, there would be good reasons to pay the compensation using public means. There is no principled argument against this, at least from a Rawlsian point of view: using public means to promote equality of opportunity is permissible, even if it comes at the cost of other distributive projects. Equality of opportunity takes priority over leximin-efficient distribution in accordance with the difference principle.

Suppose that this is the case, and that (a part of) the costs of creating equality of opportunity falls on the population as a whole. The question now becomes which part of the population should pay: all of the population or only parents? With regard to equality between men and women, it is clear that society should pay, because statistical discrimination is unfair and all have to contribute to working against it (although some may have to pay more than others for distributive justice reasons). The same reasoning seems to apply to equality between fathers and mothers. The most difficult question concerns justice between parental caregivers and non-caregivers. If one believes that the decision to parent can be counted as a legitimate reason for having less opportunities, one may either conclude equalizing opportunities is not desirable at all, or one may agree with restoring equality of opportunity if and only if the cost is borne by those deciding to create this inequality. We think that, insofar as the option sets of equally motivated people are not the same, the decision to parent creates unfair inequality concerning work opportunities - structural discrimination - and that society as a whole should contribute to levelling these unequal work opportunities.

\footnotetext{
${ }^{41}$ Of course, one may not want to assign strict lexical priority to equality of opportunity because, as Arneson points out, this would mean that we should improve the equality of opportunity of an already well-off individual a tiny bit, even at a huge cost to those who are less well-off. See Arneson (1999).
} 


\section{Conclusion}

In this paper, we have raised two questions concerning the role of firms in parental justice. First, should firms bear the business-related costs of their own employees being pregnant or being parents? Second, should they bear some of the nonbusiness costs of children? We have answered the first question negatively and the second positively, both for reasons of fairness under ideal circumstances (if one accepts pro-sharing) and equality of opportunity in non-ideal circumstances. According to a pro-sharing approach, fairness requires that firms bear some of the business-related and non-business costs of producing children; these costs should be spread across firms in proportion to their total payroll. Businessrelated costs in particular should not be left to the chance of having one's employees become parents. Rather, firms should jointly share the burden of business-related costs, along with parents and society, in proportion to how much they benefit in ideal circumstances. We propose, therefore, a scheme jointly funded by firms and other scheme beneficiaries (parents and society) both for the purpose of compensating firms for their directly incurred costs and for the purpose of contributing to the non-business costs of children in ideal circumstances. This provides a response to the two issues presented at the outset of the paper: in ideal circumstances, all firms should cover some of the businessrelated costs borne by an employer for their employees' pregnancies, as well as some of the non-business costs of children, as used to be the case in France.

Those who resist this line of argument for anti-sharing reasons might still acknowledge the important instrumental role that a business-funded insurance scheme could play in ensuring fair equality of opportunity in society for men and women, fathers and mothers, and perhaps also between parental caregivers and non-caregivers. Compensating firms for the business-related costs they incur would be a way of eliminating the statistical gender discrimination that still plagues the economic world, as well as structural discrimination. Such a business-funded insurance scheme should compensate firms for the costs of pregnancy and parenthood they may incur, not for reasons of fairness but to disincentivize the wrongful yet enduring discriminatory practices of the workplace. While this argument may be more widely embraced due to its appeal to the generally accepted FEO principle, its compensatory reach is more limited, because it compensates firms for their costs but not parents. Yet considering the costs of children for business focuses attention on a new domain - the productive sphere - and new policies to address the conflicting demands of various and equally important liberal values without compromising any of them. Establishing whether such a scheme is desirable all things considered is a legitimate question that requires further attention but goes beyond the scope of this article.

Acknowledgements. We are grateful for the comments and discussion on the arguments presented here offered by Alan Strudler, Anca Gheaus, Amy Sepinwall, Axel Gosseries, Bruno Verbeek, David Axelsen, David de la Croix, Eric Orts, Florian Wettstein, Ingrid Robeyns, Jens Damgaard-Thyssen, Lisa Herzog, Nicholas Vrousalis, Nir Eyal, Patrick Tomlin, Rutger Claassen, Serena Olsaretti, Siba Harb, Thierry Ngosso, Tom Parr and Wayne Norman. We are grateful to the two anonymous referees of this journal 
for their very constructive comments and suggestions. We also want to thank the participants at the following events: the Aarhus-Louvain workshop on theories of justice; the Yaoundé Seminar; the Economic Ethics Network; the EIASM $3^{\text {rd }}$ Workshop on Business Ethics; the Zicklin Center Normative Business Ethics Workshop; the Cercle d'Ethique des Affaires; and the Society for Business Ethics Annual Meeting.

Financial support. This project has received funding from the European Research Council (ERC) under the European Union's Horizon 2020 research and innovation programme (grant agreement No 726153).

\section{References}

Alstott A. 2004. No Exit: What Parents Owe Their Children and What Society Owes Parents. Oxford: Oxford University Press.

Arneson R. J. 1989. Equality and equal opportunity for welfare. Philosophical Studies 56, 77-93.

Arneson R. J. 1999. Against Rawlsian equality of opportunity. Philosophical Studies 93, 77-112.

Avi-Yonah R. S. 2004. Corporations, society, and the state: a defense of the corporate tax. Virginia Law Review 90, 1193-1255.

Becker G. S. 1981. A Treatise on the Family. Cambridge, MA: Harvard University Press.

Beffy M., R. Roussel, J. Solard, M. Mikou and C. Ferretti (ed.) 2015. La Protection Sociale en France et en Europe en 2013. Edition 2015. Paris: DREES, Collection Etudes et Statistiques.

Blanc S. and I. Al-Amoudi 2013. Corporate institutions in a weakening welfare state: a Rawlsian perspective. Business Ethics Quarterly 23, 497-525.

Bou-Habib P. 2010. Who should pay for higher education? Journal of Philosophy of Education 44, 479-495.

Brighouse H. and A. Swift 2014. Family Value. Princeton, NJ: Princeton University Press.

Brighouse H. and E. O. Wright 2008. Strong gender egalitarianism. Politics and Society 36, 360-372.

Budig M. J. and P. England 2001. The wage penalty for motherhood. American Sociological Review 66, 204-225.

Cahuc P. and S. Carcillo 2012. Les conséquences des allégements généraux de cotisations patronales sur les bas salaires. Revue française d'économie 27, 19-61.

Casal P. 1999. Environmentalism, procreation, and the principle of fairness. Public Affairs Quarterly 13, 363-376.

Casal P. and A. Williams 1995. Rights, equality and procreation. Analyse and Kritik 93-116.

Cohen G. A. 2000. If You Are an Egalitarian, How Come You're So Rich? Cambridge, MA: Harvard University Press.

Cour des Comptes 2013. Le Financement de la Branche Famille. https://www.ccomptes.fr/sites/default/files/ EzPublish/rapport_financement_branche_famille.pdf.

De Briey L. and Ph. Van Parijs 2002. La justice linguistique comme justice coopérative. Revue de Philosophie Economique 5, 5-38.

Dietsch P. 2015. Catching Capital. New York, NY: Oxford University Press.

Fama E. F. 1980. Agency problems and the theory of the firm. Journal of Political Economy 88, 288-307.

Fama E. F. and M. C. Jensen 1983. Separation of ownership and control. Journal of Law and Economics 26, 301-325.

Federici S. 2012. Justice at Point Zero. New York, NY: PM Press.

Ferguson L. 2013. Gender, work, and the sexual division of labor. In The Oxford Handbook of Gender and Politics, ed. G. Waylen, K. Celis, J. Kantola and S.L. Weldon. Oxford: Oxford University Press.

Folbre N. 2008. Valuing Children. Cambridge, MA: Harvard University Press.

George R. 1987. Who should bear the cost of children? Public Affairs Quarterly 1, 1-42.

Gheaus A. and I. Robeyns 2011. Equality-promoting parental leave. Journal of Social Philosophy 42, 173-191.

Gosseries A. 2004. Historical emissions and free-riding. Ethical Perspectives 11, 36-60.

Gosseries A. 2009. Three models of intergenerational reciprocity. In Intergenerational Justice, ed. A. Gosseries and L. Meyer, 119-146. Oxford: Oxford University Press.

Hamrouni N. and P.-Y. Néron 2017. Justice, gender, and corporations: outline of a feminist political philosophy of the corporation. World Political Science 13, 193-219. 
Hart H. L. A. 1955. Are there any natural rights? Philosophical Review 64, 175-191.

Heath J. 2013. The structure of intergenerational cooperation. Philosophy and Public Affairs 41, 31-66.

Herzog L. and A. Gheaus 2016. The goods of work (other than money!) Journal of Social Philosophy 47, $70-89$.

Hsieh N. 2005. Rawlsian justice and workplace republicanism. Social Theory and Practice 31, 115-142.

Hsieh N. 2008. Survey article: justice in production. Journal of Political Philosophy 16, 72-100.

Hussain W. 2009. The most stable just regime. Journal of Social Philosophy 40, 412-433.

Issacharoff S. and E. Rosenblum 1994. Women and the workplace: accommodating the demands of pregnancy. Columbia Law Review 94, 2154-2221.

Jensen M. C. and W. H. Meckling 1976. Theory of the firm: managerial behavior, agency costs and ownership structure. Journal of Financial Economics 3, 305-360.

Kmec J., M. L. Huffman and A. M. Penner 2014. Being a parent or having a parent? The perceived employability of men and women who take employment leave. American Behavioral Scientist 58, 452-472.

Lippert-Rasmussen K. 2014. Born Free and Equal. Oxford: Oxford University Press.

List C. and Ph. Pettit 2011. Group Agency: The Possibility, Design, and Status of Corporate Agents. New York, NY: Oxford University Press.

Mason A. 2000. Equality, personal responsibility, and gender socialisation. Proceedings of the Aristotelian Society 100, 227-246.

MEDEF. 2011. Le Nouveau Pacte Fiscal et Social pour la Compétitivité de la France. http://www.medef.com/ medef-tv/actualites/detail/article/le-nouveau-pacte-fiscal-et-social-pour-la-competitivite-de-la-france. html.

Meijers T. 2016. Justice in Procreation. PhD Thesis, University of Louvain.

Meijers T. 2017. Citizens in appropriate numbers. Canadian Journal of Philosophy. 47, 246-268.

Néron P.-Y. 2015. Rethinking the very idea of egalitarian markets and corporations: why relationships might matter more than distribution. Business Ethics Quarterly 25, 93-124.

Olsaretti S. 2013. Children as public goods? Philosophy and Public Affairs 41, 226-258.

O'Neill O. 2001. Agents of justice. Metaphilosophy 32, 180-195.

O'Neill M. 2008. Three Rawlsian routes towards economic democracy. Revue de Philosophie Economique 9, 29-55.

O'Neill M. 2009. Entreprises et conventionnalisme: Régulation, Impôt et Justice Sociale, Raison Publique 10, 171-200.

Orts E. W. and A. Sepinwall 2015. Privacy and organizational persons. Minnesota Law Review 99: 2275-2322.

Pettit Ph. 2014. Deux sophismes à propos des personnes morales. Raisons Politiques 4, 5-23.

Phillips A. 2006. Really equal: opportunities and autonomy. Journal of Political Philosophy 14, 18-32.

Quong J. 2006. Cultural exemptions, expensive tastes, and equal opportunities. Journal of Applied Philosophy 23, 53-71.

Rakowski E. 1991. Equal Justice. Oxford: Oxford University Press.

Rawls J. B. 1971. A Theory of Justice. Cambridge, MA: Belknap Press of Harvard University Press.

Rawls J. B. 1999. A Theory of Justice. Revised Edition. Cambridge, MA: Belknap Press of Harvard University Press.

Singer A. 2015. There is no Rawlsian theory of corporate governance. Business Ethics Quarterly 25, 1-28.

Tomlin P. 2015. Should kids pay their own way? Political Studies 63, 663-678.

US Bureau of Labor Statistics 2015. Annual Time Use Survey, Labor. http://www.bls.gov/news.release/atus. t01.htm.

Van Parijs P. 2002. Linguistic justice. Philosophy, Politics and Economics 1, 59-75.

Waldfogel J. 1997. The effect of children on women's wages. American Sociological Review 62, 209-217.

Waldfogel J. 1998. Understanding the "family gap" in pay for women with children. The Journal of Economic Perspectives 12, 137-156.

Williams A. 2002. Dworkin on capability. Ethics 113, 23-39.

Yavorsky J. E., C. M. Kamp Dush and S. J. Schoppe-Sullivan 2015. The production of inequality: the gender division of labor across the transition to parenthood. Journal of Marriage and Family 77, 662-679. 
Young I. M. 1990. Justice and the Politics of Difference. Princeton, NJ: Princeton University Press.

Young v. United Parcel Service, Inc. 575 U.S. (2015). http://www.supremecourt.gov/opinions/14pdf/ 12-1226_k5fl.pdf.

Sandrine Blanc is Assistant Professor of Business Ethics at the Faculty of Economics and Business and the Institute of Philosophy at KU Leuven. Her research focuses on normative issues concerning corporations and contemporary capitalism. She has a particular interest in the significance and implications of social justice for corporations. Her publications include articles in Business Ethics Quarterly, Journal of Business Ethics and Revue de Philosophie Economique.

Tim Meijers is a postdoctoral researcher on the ERC Fair Limits project at Utrecht University and Assistant Professor at Leiden University. He obtained his PhD from the University of Louvain (Hoover Chair). He writes on intergenerational justice, family ethics, reproductive rights, agents of justice and the ethics of migration. His papers have appeared in journals such as Canadian Journal of Philosophy, Ethics and International Affairs, Critical Review of International Social and Political Philosophy and Human Rights Quarterly.

Cite this article: Blanc S and Meijers T (2020). Firms and parental justice: should firms contribute to the cost of parenthood and procreation? Economics \& Philosophy 36, 1-27. https://doi.org/10.1017/ S0266267119000014 